\title{
ADMINISTRATIVE TERRITORIAL REFORM - WHAT CHANGES DO VILLAGE COMMUNITIES NEED
}

\author{
${ }^{1}$ Olha FILONENKO, ${ }^{2}$ Yuriy FILONENKO \\ 'Taras Shevchenko National University of Kyiv, Ukraine \\ ${ }^{2}$ Nizhyn Mykola Hohol State University, Ukraine \\ 'urij_filonenko@mail.ru
}

\begin{abstract}
A lot of European countries have already implemented a reform of administrative-territorial structure. Our country is also facing this problem: being a part of the former USSR, its administrative-territorial structure has been repeatedly changing (some administrative-territorial units disappeared, the new ones appeared; boundaries of regions and districts changed as well as their number). Inefficiency of administration in Ukrainian regions is so obvious, that immediate and decisive actions are required. The question is how reformation will be conducted and how effective it will be from the point of view of state and regional management and social-economic life of communities.

Certainly, the country's leadership insists on "voluntary" radical changes. To make these changes there are a necessary legislative framework, agreement on financing, the orders of the government and regional administrations, etc. But there is another way, for example, to eliminate regions, to enlarge districts, to create counties, to shorten the apparatus in rural councils and to keep only the heads of these councils. Those persons, who apply for the position of the head of the council, should be at the same time registrated as candidates for deputies of the county council. In the case of election, they would lead the community and represent them at the district level. In addition, all the resources which belong to now existing rural communities, but are not controlled by them because of different reasons, should be immediately transmitted to their disposal. It will create conditions for their financial independence.

An effective implementation of administrative functions by the leadership of the newly formed communities and counties for ensuring their socio-economic and cultural development has to become the main result of administrative-territorial reform.
\end{abstract}

Key words: administrative-territorial reform, management, community, village council, innovation, financial state, infrastructure.

DOI: http://dx.doi.org/10.17721/2413-7154/2016.75.7-11

UDC: 911.3

\section{АДМІНІСТРАТИВНО-ТЕРИТОРІАЛЬНА РЕФОРМА - ЯКІ ЗМІНИ ПОТРІБНІ СІЛЬСЬКИМ ГРОМАДАМ}

'ОЛЬГа ФІЛОНЕНКО, ²Юрій ФІЛОНЕНКО

\author{
'Київський начіональний університет імені Тараса Шевченка, Україна \\ ${ }^{2}$ Ніжинський державний університет імені Миколи Гоголя, м. Ніжин, Україна \\ 'urij_filonenko@mail.ru
}

\begin{abstract}
Анотація: Багато країн Європи вже провели реформу адміністративно-територіального устрою. Перед цією проблемою стоїть і наша країна, яка, перебуваючи у складі колишнього СРСР, неодноразово зазнавала змін адміністративно-територіального устрою (зникали одні адміністративно-територіальні одиниці та з'являлися інші, змінювалися межі областей та районів, а також їх кількість). Неефективність управління регіонами в Україні нині настільки очевидна, що вимагає негайних і рішучих дій. Питання полягає лише в тому, яким чином здійснюватиметься реформування і наскільки воно буде ефективним з точки зору державного та регіонального управління і соціально-економічного життя громад.

Зрозуміло, що керівництво держави наполягає на «добровільних» радикальних змінах. Для цього вже $\epsilon$ необхідна законодавча база, угода про фінансування, розпорядження уряду та обласних адміністрацій тощо. Але можна піти й іншим шляхом. Наприклад, ліквідувати області й, укрупнивши райони, створити округи (повіти), а також скоротити апарат працюючих у сільських радах, залишивши лише голів (старост). Осіб, які будуть претендувати на посади голів, варто одночасно реєструвати й кандидатами у повітові депутати. У разі обрання, вони будуть і очолювати громади, і представляти їх на районному рівні. Крім того, у розпорядження нині існуючим сільським громадам необхідно негайно передати ресурси, які їм же й належать, але, в силу різних причин, ними не контролюються. Це вже зараз створить умови для їх фінансової незалежності.

Головним результатом адміністративно-територіальної реформи має стати ефективне здійснення управлінських функцій керівництвом новостворених громад та повітів для забезпечення їх соціально-економічного та культурного розвитку.

Ключові слова: адміністративно-територіальна реформа, управління, громада, сільська рада, нововведення, фінансовий стан, інфраструктура.
\end{abstract}

DOI: http://dx.doi.org/10.17721/2413-7154/2016.75.7-11

удк: 911.3

( ) О. Філоненко, Ю. Філоненко 
Вступ. Постановка проблеми. В умовах переходу від командно-адміністративної до ринкової економіки у невеликих населених пунктах відбулося значне скорочення виробництва або повна зупинка наявних промислових підприємств. Наслідком цього стало різке зменшення надходження коштів до місцевих бюджетів, тотальне безробіття та значне скорочення населення. В таких умовах саме життя диктує необхідність змін, і питання ефективного управління адміністративно-територіальними одиницями та збереження ї інфраструктури набуває важливого значення. Найголовнішим $є$ визначення того, які саме зміни потрібні і яке покращення в житті громад вони здатні забезпечити у короткочасній перспективі. Чи варто зробити радикальні зміни передбачені новим законодавством $[8,9,10]$, чи лише ліквідувати області й, укрупнивши райони, створити округи (повіти) одночасно ліквідувавши ОДА (обласні державні адміністрації) та РДА (районні державні адміністраціі), чи може надати можливість нині існуючим сільським громадам розпоряджатися ресурсами, які їм же й належать, але, в силу різних причин, ними не контролюються. На нашу думку, реформування адміністративно-територіального устрою має враховувати природні, економічні, історичні, етнічні, культурні, соціальні та інші чинники, які нині впливають на соціально-економічний розвиток існуючих громад, а в майбутньому серйозно впливатимуть на соціально-економічне життя новоутворених об'єднань громадян.

Аналіз останніх досліджень i публікацій. Дослідженню особливостей проведення адміністративно-територіальної реформи нашої держави присвячені роботи багатьох фахівців у галузі державного управління, соціально-економічної географії, регіональної економіки тощо. Так, зокрема, Р. Безсмертний наголошує на тому, що територіальна реформа $\epsilon$ базовою, але має проводитися разом із зміною чи перерозподілом повноважень, бюджетною та фіскальною реформами [4]. О. Кучабський обгрунтовує доцільність реалізації реформи адміністративно-територіального устрою в державі після досягнення конкретних результатів реформ соціально-економічного характеру та реорганізації системи управління [13]. Ф. Панасюк відзначає, що адміністративно-територіальна, податкова та бюджетна реформи мають відбуватися одночасно, a ïx найважливішим компонентом повинна стати реформа міжбюджетних відносин, яка здатна створити умови для прозорого i прогнозованого розподілу матеріальних та фінансових ресурсів [15]. С. Пирожков та А. Павлюк наголошують, що адміністративно-територіальна реформа повинна проводитись у тісному взаємозв'язку з бюджетним, податковим та муніципальним реформуванням, а також реформуванням усього комплексу галузей сфери послуг [16]. Н. Сорокіна аналізує проблеми, що гальмують проведення ефективних соціальноекономічних перетворень [21]. А. Черемис та М. Лесечко вважають, що одночасно з адміністративною реформою мають відбуватися, або навіть випереджати іiі, реформи освіти, охорони здоров'я, соціального забезпечення та судової системи [22]. Ця ж тематика висвітлюється і в роботах В. Яцуби, В. Яцюка, О. Матвіїшина, М. Барановського, Ю. Ганущака, Б. Данилишина, А. Павлюка, М. Пухтинського [1, 2, 3, 5, 6, 14, 20].

Опрацювання зазначених публікацій показує, що багато проблем пов'язаних 3 проведення реформи залишаються недостатньо дослідженими, і це питання ще тривалий час буде вкрай актуальним для влади, науковців та громадян України.

Формування цілей. Постановка завдання. Метою даного дослідження є висвітлення окремих особливостей та проблем адміністративнотериторіальної реформи в Україні. Мета пов'язана iз виконанням таких завдань: виявлення та аналіз найбільш прийнятних для громадян та держави умов формування громад; вивчення можливостей отримання громадами матеріальних та фінансових ресурсів.

Виклад основного матеріалу. Питання проведення реформ - це завжди питання грошей. У випадку 3 реформою адміністративно-територіального устрою - це питання кількості грошей, які виділяються 3 державного бюджету на утримання управлінського апарату на регіональному рівні, закладів освіти, культури, охорони здоров'я тощо. Зрозуміло, що цих коштів немає у достатній кількості і держава мусить економити. Тим більше, що існує об'єктивний процес скорочення сільського населення, через який проходили у свій час всі країни світу, що стали на рейки ринкової економіки.

Без сумніву, при наявності сучасних засобів виробництва, сільське господарство не потребує значної кількості робочої сили. Саме тому, навіть за великого відсотку людей літнього віку та при малій людності населених пунктів, у сільській місцевості практично по всій країні спостерігається надлишок робочих рук. Це змушує працездатних громадян шукати кращої долі у містах та за кордоном. Очевидно, що кількість сільського населення і надалі буде зменшуватися, а самі населені пункти зникатимуть 3 карти України. На жаль, цей процес $є$ незворотнім. Питання лише в тому, наскільки швидко і з якими особливостями, матеріальними та психологічними наслідками для селян він буде відбуватися.

Виходячи з цього, зрозуміло, що адміністративнотериторіальна реформа в Україні давно назріла і іiі потрібно проводити. Необхідні закони прийнято $[8,9$, 10], угоду про фінансування («Контракт для України 3 розбудови держави») цього загальнодержавного заходу підписано $[7,11,12]$, розпорядження уряду та обласних адміністрацій для втілення реформи в життя зроблено $[18,19]$. Але при ознайомленні 3 пропонованим варіантом адміністративнотериторальної реформи виникає ряд питань, пов'язаних з втіленням іiі в життя і з тим, чи обов'язково саме такого варіанту реформи дотримуватися.

Як показують результати опитування мешканців сіл, отримані нами під час сільських сходів, більшість селян вважає реформу важкою 3 психологічної та матеріальної точки зору. Людям складно сприймати той факт, що за звичайною довідкою треба буде йти 
не до своєї сільради, а їхати в інший населений пункт, витрачаючи при цьому певну суму коштів.

Особливо негативне ставлення до можливих змін серед осіб літнього віку, які є домінуючою віковою групою населення у сільській місцевості. Серед них поширена «колгоспна ностальгія», засудження сучасного стану речей і несприйняття пропонованої адміністративно-територіальної реформи.

За часів колишнього СРСР мешканці сіл, обираючи голів населених пунктів i депутатів сільських рад, чітко усвідомлювали, що вони не $\epsilon$ реальною владою на селі. Селяни розуміли, що насправді реальна влада була в того, хто володів матеріальними та фінансовими ресурсами. А це були керівники колгоспів, радгоспів, селекційно-дослідних станцій тощо. Селянин знав, що фінансову та матеріальну допомогу (виписати паливо, транспорт, зерно, будівельні матеріали) можна отримати, звернувшися саме до них. Саме від керівників господарств, а не від голів селищних чи сільських рад, залежало, чи будуть очищені від снігу дороги, чи нормально функціонуватиме вуличне освітлення, яким буде харчування дітей у школах та дитсадках, як будуть облаштовуватися сільські стадіони й спортивні майданчики тощо.

3 розпадом колективних господарств проблеми сіл та їх мешканців вирішувати стало нікому. Підприємства, які зараз діють у сільській місцевості і мають певні матеріальні ресурси та фінансові можливості (агрохолдинги, птахофабрики, агролісництва та ін.), інколи допомагають сільським громадам, але вони намагаються уникникати додаткових витрат. Пріоритетною для них $є$ власна господарська діяльність, а не вирішення різноманітних питань, пов'язаних із забезпеченням нормального функціонування нинішніх сільських громад.

У більшості населених пунктів усі проблеми i труднощі лягли на плечі самих громадян. Виняток становлять лише окремі сільські ради, які очолюють ініціативні керівники. На жаль, люди вже звикли до такого стану речей i розраховують лише на самих себе. Коли ж з'явилася інформація про адміністративно-територіальну реформу, то, не дивлячися на труднощі сучасного життя, сама ідея можливих радикальних змін викликала в мешканців сільських громад тривогу i занепокоєння. Люди скептично ставляться до самої ідеї «добровільності» об'єднання. Їх хвилює, що являтиме собою громада та повіт. До кого потрібно звертатися для оформлення різноманітних документів, коли не буде сільської ради? Яка буде ситуація 3 транспортом, освітленням вулиць, ремонтом доріг тощо? Хто буде утримувати в робочому стані меліоративні системи - Держводагентство, новоутворена громада, повіт чи орендаторі паїв? Це дуже короткий перелік питань, які ставлять громадяни перед нинішніми очільниками областей, районів та населених пунктів.

Попри заявлені можливості отримання фінансів громадами в розмірі 5\% акцизного податку, 60\% податку на доходи фізичних осіб, 100\% на прибуток підприємств комунальної форми власності, 25\% екологічного податку, $100 \%$ єдиного податку, а також державне мито, туристичний збір, оренда за використання водойм, рента за користування надрами тощо - все це поки що не переконує громадян у доцільності нових об'єднань. Вони бачать у адмінреформі зміну свого і без того не легкого життя не в кращий бік

Для пом'якшення сприйняття нововведень мешканцями сіл потрібно, на нашу думку, формуючи межі майбутніх повітів не приєднувати їх механічно в існуючих межах, а максимально врахувати наявність природних географічних меж - річок, гірських хребтів тощо. Це потрібно для уникнення появи «відрізаних» населених пунктів, які мали місце, зокрема у Чернігівській області, коли основна частина району розташовується на одному березі Десни, а одне чи кілька сіл - на протилежному. Також дуже важливим, якщо не найголовнішим, $є$ врахування роками усталеного транспортного сполучення (головним чином, автобусних маршрутів).

Щодо формування громад, то, на наш погляд, на нинішньому етапі розвитку України, доцільно буде відмовитися від об'єднання населених пунктів у нові громади і прирівняти до громад населені пункти, що мають сільські ради. Беручи до уваги той факт, що суть реформи, щоб там не прописувалося у законах, полягає не у міфічних можливостях для людей, а однозначно в скороченні бюджетних витрат на адмінапарат, сільських освітян, медиків тощо, то варто було б автоматично прирівняти посаду сільського голови до старости й ліквідувати посади секретарів та бухгалтерів. Паперової роботи в селах не так багато і одна людина 3 цим повністю впоралася б. До того ж, і самі приміщення сільських рад, на утримання яких також витрачаються кошти (освітлення, опалення тощо) можна або продати, або здавати в оренду, отримуючи кошти для громади.

Старости сіл (громад) мають виконувати подвійну функцію - очолювати населений пункт і одночасно представляти його на районному (повітовому) рівні. Тобто люди в особі старости повинні обрати і голову села (громади) і депутата районної (повітової) ради. Досвід останніх виборів показав, що у більшості районних рад кількість депутатів близька до кількості сільських рад. Це необхідно закріпити законодавчо. Таким чином, буде встановлено прямий зв'язок між сільськими громадами й районними радами.

До речі, не має значення, як буде називатися посада керівника району (повіту) - голова РДА, Голова райради чи префект [14]. Головне, щоб він перебував на своєму місці, контролював ситуацію та відлучався лише на сесії й у справах громади, а більшість поточних питань вирішував через сучасні засоби комунікації.

Наділення голови (старости) повноваженнями районного (повітового) депутата створить умови, коли мешканці сіл сприйматимуть депутата, як свого представника на районному рівні. Це буде справжній очільник і представник громади, що живе і працює поряд 3 іншими іiі членами, а не «дистанційно» виконує свої обов'язки. Зрозуміло, що це не врятує ні школу, ні фельдшерсько-акушерський пункт, ні клуб від закриття, але люди хоча би матимуть відчуття, 
що вони в своєму селі не покинуті й не забуті. У них буде обраний ними очільник, який до того ж представляє інтереси села на рівні району (повіту).

Крім того, селяни постійно піднімають питання про ліквідацію таких утворень, як райагролісництва і про повернення лісів, посаджених самими селянами на колишніх колгоспних землях, що нині лише номінально перебувають у розпорядженні сільських рад. Фактично сільські ради розпоряджаються лише землями в межах населених пунктів, а поза їх межами землями нинішніх громад розпоряджаються РДА, що $\epsilon$ справжнім нонсенсом. Селяни також наголошують на необхідності негайного втановлення певних сум відрахувань до бюджету громад за експлуатацію наявних кар'єрів та використання сільських доріг агрохолдингами і промисловими підприємствами, а також на перереєстрації підприємств, що розміщені й діють на території сільських рад, але мають інше місце реєстрації i, відповідно, не сплачують усіх можливих податків.

Важливим $є$ й питання екологічного збору. Мешканці сільських громад вимагають узгодження 3 ними використання на полях пестицидів, гербіцидів та засобів росту рослин і створення спеціальних екологічних рахунків (або навіть фондів) для сільських рад. Кошти 3 цих рахунків можна буде використати на очищення наявних водойм, поглиблення колодязів, будівництво водогонів, створення нових та оновлення існуючих лісосмуг, облаштування сміттєзвалищ (особливо міських на території сільських громад) або утилізацію сміття тощо.

Такі кроки вже зараз, без втілення реформи в життя, дозволять багатьом селам отримати необхідні матеріальні та фінансові ресурси для покращення транспортної інфраструктури, соціальної сфери тощо. Це може створити умови, коли багато навіть маленьких сіл стане самодостатніми. Вони вже не будуть вимагати бюджетних грошей і їх не треба буде добровільно-примусово «заганяти» у великі громади.

Щодо шкіл, лікарень, дитячих садків, бібліотек і клубів, то вони, на жаль, будуть закриватися незалежно від того, якого розміру громада, оскільки жодна громада і жодна країна світу не може собі дозволити утримання школи, де вчителів працює більше, ніж навчається дітей і лікарні, де медперсоналу більше, ніж хворих. Тому вони будуть поступово закриватися i перед людьми поставатиме питання, яким чином дістатися до школи чи лікарні. Вирішення цього питання залежатиме не від того в малій чи великій громаді проживають люди, а від матеріального забезпечення їх родин. Хтось зможе кожного дня возити дитину до школи, хтось обере інтернатний спосіб навчання, а хтось змушений буде заради дітей змінити місце проживання.

Це значною мірою стосуватиметься й лікарень, адже наївним буде вважати, що люди у переважній більшості будуть лікуватися в існуючих чи новостворених лікарнях громад. Вони навряд чи ламатимуть свої нинішні звички і продовжать традиційно орієнтуватися на районні (повітові) та обласні медичні заклади, а дехто й на окремих лікарів.

Необхідно також чітко усвідомлювати, що адміністративно-територіальна реформа має відбуватися синхронно 3 іншими реформами (судовою, податковою, правоохоронних органів тощо), оскільки в процесі втілення їі в життя буде багато проблем i конфліктів (майнових, фінансових тощо), які потребуватимуть оперативного вирішення. Затягування 3 вирішенням можливих проблем постійно створюватиме напруженість у житті громад.

Висновки і перспективи подалыших розробок. Підсумовуючи все вище сказане, можна зробити висновок, що головна проблема полягає не в тому, якими $є$ або будуть за площею та складом адміністративно-територіальні одиниці, а в тому, наскільки ефективно буде здійснюватися управління громадами та повітами і організована їх економічна діяльність. $Є$ всі підстави стверджувати, що за умови скорочення апарату працюючих у сільських радах, наділення голів (старост) ще й повноваженнями районних (повітових) депутатів та передачі реальних джерел отримання фінансів у руки громади можна вже зараз, ще до повноцінного втілення адміністративно-територіальної реформи, суттєво покращити фінансовий стан існуючих сільських громад. Подальші дослідження 3 даної тематики $€$ важливими, оскільки дозволять більш детально проаналізувати особливості проведення адміністративно-територіальної реформи в нашій державі та розробити прогноз соціально-економічного розвитку, як існуючих, так і новоутворених громад.

\section{References:}

1. Âcuba V. G., Âcûk V. A., Matvìišin O. Â. et al. Adminìstrativno-teritorìal'nij ustrìj Ukraïni: šlâhi reformuvannâ [Administrative-territorial structure of Ukraine: ways to reform]. Kyiv, 2007, 365 p. (In Ukrainian).

2. Baranovs'kij M.O. Administrativno-teritorial'na reforma na Černigivsîini. Ŝ bude - rozkvit či zanepad? [Administrative-territorial reform in Chernihiv region. What will happen: flowering or decline?]. Access mode: http:// www.mynizhyn.com/news/misto-i-region/2224-administrativno-teritorialna-reforma-na-chernigivshini-sho-buderozkvit-chi-zanepad.html. (In Ukrainian).

3. Bezsmertnij R.P. Problemi reformuvannâ admìnìstrativno-teritorìal'nogo ustroû [The problems of reforming of administrative-territorial structure]. In: Problemi reformuvannâ publičnoï vladi: zbirnik materìaliv ì dokumentiv [Problems of public power reforming: a collection of materials and documents], Ed: Bezsmertnij R., Puhtins'kij M. Kyiv, 2009, pp. 141-152. (In Ukrainian).

4. Bezsmertnij R. P. Osnovnì zasadi admìnìstrativno-teritorìal'noï reformi v Ukraïnì [The main principles of administrative-territorial reform in Ukraine]. In: Reforma dlâ lûdini: zbìrnik materìaliv pro šlâhi realizaciì 
administrativno-teritorial'noï reformi v Ukraïnì [Reform for the people: collection of materials on ways of implementing administrative-territorial reform in Ukraine] Ed: Bezsmertnij R. Kyiv, 2005, pp. 76-129. (In Ukrainian).

5. Ganuŝak Û. Reforma teritorial'noï organizaciï vladi [The reform of territorial organization of power]. Kyiv, DESPRO, 2013, 160 p. (In Ukrainian).

6. Danilišin B.M. Decentralizaciâ upravlìnnâ v Ukraïnì: z čogo počati [Decentralization in Ukraine: how to start]. Access mode: http://kontrakty.ua/category/238. (In Ukrainian).

7. ÊS vidilâê 250 mill'jonìv êvro bezpovorotnoï dopomogi v ramkah Kontraktu dlâ Ukraïni z rozbudovi deržavi [EU grants 250 million euros of irrevocable aid to Ukraine in the framework of the Contract for the State Development]. Delegation of the European Union to Ukraine: Official website. Access mode: http://eeas.europa.eu/delegations/ukraine/ press_corner/all_news/news/2014/2014_06_13_01_uk.htm. (In Ukrainian).

8. The Law of Ukraine "On Principles of the State Regional Policy" dated February 3, 2015 N 156-VIII. Access mode: zakon.rada.gov.ua/go/156-19. (In Ukrainian).

9. The Law of Ukraine "On voluntary consolidation of territorial communities" dated February 5, 2015 N $157-$ VIII. Access mode: zakon.rada.gov.ua/go/157-19. (In Ukrainian).

10. The Law of Ukraine "On cooperation of territorial communities" dated 17.06.2014 N 1508-VII. Access mode: http://zakon4.rada.gov.ua/laws/show/1508-18. (In Ukrainian).

11. State Building Contract for Ukraine. Access mode: zakon.rada.gov.ua/go/452-2014-p. (In Ukrainian).

12. State Building Contract for Ukraine Part 2. Access mode: http://www.cpsa.org.ua/novyny/kontrakt-zrozbudovy-derzhavy-ch-2/. (In Ukrainian).

13. Kučabs'kij O. G. Admìnìstrativno-teritorìal'na reforma v sistemì suspìl'nih reform Ukraïni [Administrativeterritorial reform in the system of social reforms of Ukraine]. Visnik Nacional'nö̈ akademï deržavnogo upravlinnâ pri Prezidentovì Ukraïni [Bulletin of the Ukrainian Academy of Public Administration], 2009, N. 9, pp. 168-175. (In Ukrainian).

14. Pavlûk A. P. Reformuvannâ admìnìstrativno-teritorìal'nogo ustroû âk činnik regìonal'nogo rozvitku v Ukraïnì [Reform of the administrative-territorial system as a factor of regional development in Ukraine]. In: Deržavna regional'na politika Ukraïni: osoblivostì ta strategičnì prìriteti [State Regional Policy of Ukraine: features and strategic priorities], Ed: Varnalij Z. Kyiv, 2007, pp. 328-330. (In Ukrainian).

15. Panasûk F. Zmìst ì zavdannâ sistemnogo uporâdkuvannâ deržavnogo regulûvannâ rozvitku teritorìj [The content and objectives of system ordering of the state regulation of territorial development]. Visnik Nacional'nö̈ akademï̈ deržavnogo upravlinnâ pri Prezidentovì Ukrä̈ni [Bulletin of the Ukrainian Academy of Public Administration], 2001, N. 2, P. 1, pp. 32-43. (In Ukrainian).

16. Pirožkov S., Pavlûk A. Admìnìstrativno-teritorìal'na reforma v Ukraïnì: aktual'nì pitannâ metodologiii ta praktiki [Administrative-territorial reform in Ukraine: issues of methodology and practice]. Ekonomika Ukraïni [Economy of Ukraine], 2005, Vol. 7, pp. 4-14. (In Ukrainian).

17. Workplan of the Office of Reforms in Kyiv Region. Access mode: www.kyiv-obl.gov.ua/plan_roboti_ofisu_ reform. (In Ukrainian).

18. Resolution of the Cabinet of Ministers of Ukraine «On Approval of the State Strategy of Regional Development up to 2020» dated August 6, 2014 N 385. Access mode: http://zakon4.rada.gov.ua/laws/show/385-2014-\%D0\%BF/. (In Ukrainian).

19. Resolution of the Cabinet of Ministers of Ukraine «On Approval of the plan of measures on realization of the Concept of reforming the local self-government and territorial organization of power in Ukraine» dated June 18, 2014, N 591-r. Access mode: http://zakon2.rada.gov.ua/laws/show/591-2014-\%D1\%80. (In Ukrainian).

20. Puhtins'kij M. O. Konceptual'nì ta prikladnì aspekti zdìjsnennâ admìnìstrativnoï reformi v Ukraïnì [Conceptual and practical aspects of implementation of administrative reform in Ukraine]. In: Administrativna reforma v Ukrä̈ni: šlâh do Êvropejs 'koï integraciï [Administrative reform in Ukraine: the path to European integration]. Kyiv, 2003, pp. 33-35. (In Ukrainian).

21. Sorokìna N. G. Reformuvannâ admìnìstrativno-teritorìal'nogo ustroû Ukraïni: problemi ta perspektivi [Reform of the administrative-territorial system of Ukraine: problems and prospects]. Publične administruvannâ: teoriâ ta praktika [Public administration: theory and practice], 2010, Vol. 1(3). Access mode: http://www.dridu.dp.ua/ zbirnik/2010-01/10sngupp.pdf. (In Ukrainian).

22. Čemeris A. O. Sistemnij pìdhìd do problemi reformuvannâ deržavnogo upravlìnnâ [Systematic approach to public administration reform]. Visnik Nacional'nö̈ akademï deržavnogo upravlìnnâ pri Prezidentovì Ukraïni [Bulletin of the Ukrainian Academy of Public Administration], 2001, N. 3, pp. 12-21. (In Ukrainian). 